\title{
Objectivity, Prescription, Harmlessness, and Drudgery: Reflections of Lexicographers in Slovenia*
}

\author{
Alenka Vrbinc, Faculty of Economics, University of Ljubljana, \\ Ljubljana, Slovenia (alenka.vrbinc@ef.uni-lj.si) \\ Donna M.T.Cr. Farina, Department of Multicultural Education, New Jersey \\ City University, New Jersey, USA (dfarina@njcu.edu) \\ and \\ Marjeta Vrbinc, Department of English, Faculty of Arts, University of \\ Ljubljana, Ljubljana, Slovenia (marjeta.vrbinc@ff.uni-lj.si)
}

\begin{abstract}
This contribution reports on a study that set out to paint as complete a picture as possible of the context and content of modern Slovenian lexicography. We aimed to discern the philosophical underpinnings, the most noteworthy accomplishments, and the main projects of Slovenian dictionary work as presented by our seven subjects, who are all prominent members of the lexicographic community. We sought specialists who work on synchronic topics and concentrate more on the standard language and terminology rather than on dialectal variation and other lexicographic topics that are of more interest to scholars than to educated lay persons. The interview script consisted of thirteen narrative questions, designed to allow the interviewees to reflect in as much depth as possible on their daily practice as well as on their underlying vision of what lexicography or terminography is. This article discusses the development and influences of Slovenian lexicographic theory and presents part 1 of the results of this study: the views of the practicing lexicographers on whether they perceive their lexicographic work as drudgery and what they see as the essential nature of their role in society - how the dictionary maker can be a force for good and avoid any potential for harm.
\end{abstract}

Keywords: HARMLESS DRUDGE, DRUDGERY, HARM, HARMLESSNESS, INTERVIEW, LEXICOGRAPHER, LEXICOGRAPHIC PHILOSOPHY, LEXICOGRAPHIC PRINCIPLES, MONOTONY, REPETITIVENESS, TEDIUM

Opsomming: Objektiwiteit, voorskriftelikheid, onskadelikheid en sleurwerk: Beskouings van leksikograwe in Slowenië. In hierdie bydrae word verslag

* A highly abbreviated summary of this article, "Slovenian Lexicographers at Work," will appear in the Proceedings of the XVIII EURALEX International Congress, 17-21 July 2018: Lexicography in Global Contexts. 
gedoen oor ' $n$ studie waarin gepoog is om so ' $n$ volledig moontlike beskrywing te gee van die konteks en inhoud van die moderne Sloweense leksikografie. Ons het probeer om die filosofiese boustene, die noemenswaardigste prestasies, en die belangrikse Sloweense woordeboekprojekte soos voorgehou deur ons sewe respondente, wat almal prominente lede van die leksikografiese gemeenskap is, weer te gee. Ons het vakkundiges gekies wat aan sinchroniese onderwerpe werk en meer op die standaardtaal en -terminologie konsentreer as op dialektiese variasie en ander leksikografiese onderwerpe, wat van meer belang is vir die vakkundige as vir die opgevoede leek. Die onderhoud het bestaan uit dertien narratiewe vrae, wat ontwerp is om die respondente toe te laat om so volledig moontlik weer te gee wat hul daaglikse praktyke is sowel as wat hul onderliggende visie van die leksikografie en terminografie is. Hierdie artikel bespreek die ontwikkeling en invloede van Sloweense leksikografiese teorie en gee deel 1 van die resultate van hierdie studie weer: die beskouings van die praktiserende leksikograwe oor of hulle hul leksikografiese werk as sleurwerk ervaar en wat hulle as die wesensaard van hul rol in die gemeenskap beskou - hoe die woordeboekmaker 'n goeie mag kan wees en enige potensiële skade kan vermy.

Sleutelwoorde: ONSKADELIKE WERKESEL, SLEURWERK, SKADE, ONSKADELIKHEID, ONDERHOUD, LEKSIKOGRAAF, LEKSIKOGRAFIESE FILOSOFIE, LEKSIKOGRAFIESE BEGINSELS, EENTONIGHEID, HERHALING, VERVELING

\section{Introduction}

To a certain degree, dictionaries are created and delivered in similar ways worldwide. Some lexicographers are aware of others' work and become familiar with new ideas via conferences and publications. Bilateral and multilateral lexicographic work takes place between organizations (such as AFRILEX, ASIALEX, DSNA, and EURALEX) or else between academies of science (such as the Austrian or Slovenian academies). Despite this seemingly favorable state of affairs, many lexicographers still labor alone without a deep awareness of what others in the field are doing, even when similar dictionaries are being created in other countries. Working on a dictionary is by its nature solitary, so to some extent not so much has changed since 1755, when Samuel Johnson, the great English lexicographer, humorously defined the word lexicographer as a "harmless drudge." While some lexicographers can network frequently through conference attendance and have time to keep abreast of the state of the art through publications, others are hard pressed to keep up with the demands on their time imposed by the tyrannic words of their focus language. In such circumstances, the average dictionary maker may be barely aware of the existence of international lexicographic thought.

The purpose of the present study is to break this solitude and provide a glimpse into the world of lexicographers whose practices may not be wellknown. To our knowledge, there have been no in-depth studies based on intensive, extensive interviews with the lexicographers of any country or culture. In the present work, we are examining Slovenian lexicography through the eyes of the seven Slovenian lexicographers whom we interviewed; our hope is that 
other researchers will replicate this work to allow insight into practices prevailing in other countries. This type of reflection within the discipline of lexicography will aid, we suggest, in the advancement of theory globally.

\section{The setting of Slovenian lexicography}

The Republic of Slovenia is a country of over two million people, located in Central Europe. One of the six republics of the former Yugoslavia, Slovenia declared independence in 1991. Slovenian, the most widely spoken language in the country, is classified genetically as a South Slavic language along with other languages spoken both within the former Yugoslavia and beyond it. Although Slovenian has a relatively small number of speakers, it nevertheless has a significant lexicographic tradition; this history, like that of many other traditions (cf. Béjoint 2016; Farina and Durman 2009; Fontenelle 2016) began with needs arising from contact between languages and cultures. In the case of Slovenian, the main contact was with the German language within the Central European cultural context.

Contact with the cultures of Central Europe influenced the eventual organization of Slovenian lexicographic work. The Slovenian Academy of Sciences was founded in 1938; within it, the Institute of the Slovenian Language where lexicographic projects are ongoing today — was established in 1945. The modern Slovenian Academy focuses on monolingual lexicography but not all monolingual work takes place exclusively within it. In 2004, the independent Trojina, Institute for Applied Slovenian Studies, was founded in Ljubljana. Through grant funding, Trojina collaborates on projects with other institutions engaging in lexicographic work, at the University of Ljubljana and beyond. Since Slovenia achieved its independence in 1991, public interest in the national language has increased. The number of monolingual projects has grown within the Academy of Sciences; there are existing dictionaries or ongoing projects on phraseology, orthography, synonymy, and terminology (to name some). In order to field an increasing number of questions from the public about language, the Academy maintains an active online consulting service. The Trojina Institute has its own online tools that are utilized to engage Slovenian speakers to the fullest extent possible in deeper reflection on their language.

Slovenian bilingual lexicographic work is conducted outside the walls of the Academy of Sciences. Presently there are pairings of Slovenian with a greater number of languages than was the case historically. For example, there now exist recent dictionaries of Slovenian with Czech, Dutch, English, French, German, Italian, Polish, Russian, Serbo-Croatian, and Spanish. Unfortunately, just as the public's interest in bilingual lexicographic tools has increased, Slovenian publishing houses have ceased to publish such dictionaries. For this reason, as one of our interviewees indicates, the future of Slovenian bilingual lexicography is unclear. 


\section{Development and influences of Slovenian lexicographic theory}

In the history of lexicography, prefaces and other front matter have usually provided some insight into a given dictionary's compilation principles (Shapiro 2017), but they have seldom been forthcoming enough to fully guide specialists or the general user. For example, Landau (2001: 64) and Béjoint (2010: 68-76) discuss Samuel Johnson's theory with references to his preface, while Jackson (2002: 42-46) points out the additional theoretical benefit of Johnson's 1747 Plan of a Dictionary of the English Language. Farina and Durman (2012: 9) contrast the original preface by Baudouin de Courtenay in his revision of an early twentieth-century Russian dictionary, with the more detailed explanations he provided in later writings - when he was trying to defend his highly-criticized compilation decisions. Slovenian lexicography has followed the same typical historical movement toward providing ever-increasing theoretical information. While the front matter to the first volume of The Dictionary of Standard Slovenian (Bajec et al. 1970) gives a detailed explanation of how to use the dictionary, this is almost impossible for a lay person to decipher. Since the 1970s but particularly in the new century, there has been a constant stream of scholarly work putting forward an underlying philosophy of what general Slovenian lexicography should be (for example: Gantar 2015; Gliha Komac et al. 2015; Gorjanc et al. 2015; Gorjanc et al. 2017; Ledinek et al. 2015; Snoj 2004; Srebnik 2015; and Žagar Karer 2011).

Both contemporary monolingual and bilingual lexicography within Slovenia have been deeply influenced by British lexicographic theory; the lexicographers interviewed for this study mentioned Sue Atkins, Patrick Hanks, R.R.K. Hartmann, Adam Kilgarriff, Michael Rundell, and John Sinclair. The interviewees also demonstrate a wide reading across many linguistic and lexicographic cultures. They mentioned Sylviane Granger (Belgium); Gilles-Maurice de Schryver (working in Belgium and South Africa); Rufus Gouws and Danie Prinsloo (South Africa); František Čermák (former Czechoslovakia and Czech Republic); Herbert Ernst Wiegand (Germany); Ute Römer (working in Germany and the United States); Dwight Bolinger, Don McCreary, Erin McKean, and Ben Zimmer (United States); Ladislav Zgusta (working in former Czechoslovakia and then the United States); Anna Wierzbicka (Poland and Australia); Juri Apresjan (former Soviet Union and Russian Federation); and Bo Svensén (Sweden). In the realm of modern terminography, the Slovenian tradition has been most influenced by the classical Vienna school of terminology.

\section{Ensuring the future of Slovenian lexicographic work}

For the authors of the present article, there is a striking contrast between the governmental and societal nurturing of lexicographic endeavors that take place in the small country of Slovenia, versus the almost entirely independent and commercial practice of the United States (as well as many other countries, such 
as Germany, the Netherlands, and the UK), where there is little to no government funding of dictionary work. In Slovenia there are university courses designed to introduce graduate students to lexicographic theory; such courses are rare across the United States. At the University of Ljubljana alone, there are two graduate courses on monolingual lexicography; there is also a short graduate course on bilingual lexicography. At the University of Maribor, a much smaller institution than the University of Ljubljana, there is a graduate course on lexicography and another course that treats dictionaries as a cultural practice. What is more, the official curriculum for all public and private Slovenian high schools has several components intended to familiarize students with dictionaries and their purposes; there is a question about dictionaries on the official high school final exam. Certainly, the visibility of both high school and university programs of dictionary study is an important factor both in maintaining the interest of the general public in dictionaries and in the Slovenian language, and in ensuring that lexicography will remain a viable discipline as well as a career field for some.

Slovenia has taken other steps to ensure the future development of lexicographic practice and theory. Since 1985, the Young Researchers Program has selected talented master's and doctoral students to work in industry, university departments, and institutes both within the Academy of Sciences and beyond; lexicography is one of many fields of study to benefit from this program. By training the future cadre of practicing lexicographers, the program has helped move forward the professionalism of the discipline. Four out of the seven interviewees for this project - as well as two authors of this article - began their lexicographic careers within the Young Researchers Program.

\section{Aims of the study}

This study set out to paint as complete a picture as possible of the context and content of modern Slovenian lexicography. We aimed to discern the philosophical underpinnings, the most noteworthy accomplishments, and the main projects of Slovenian dictionary work as presented by our seven subjects, who are all prominent members of the lexicographic community. For this study only seven persons were interviewed, so we do not claim to present a comprehensive picture; our findings would most likely require revision if additional subjects were consulted. Nevertheless, because we interviewed lexicographers working on different projects and within several institutions, who have different duties and approaches that vary significantly, we do claim that this study captures some of the most important issues in Slovenian lexicography today. This study should be of interest to lexicographers worldwide who want to reflect upon their own practice, their country's or culture's practice of making dictionaries. Through a look at the work lives of Slovenian lexicographers, dictionary makers internationally stand to gain a better understanding of what they most want to do at home to improve our field. Lexicographic practice 
around the globe would benefit if other researchers replicated this study or used components of it as a departure point for the examination of other lexicographic cultures. Finally, apart from the more immediate aims of this work, we hope that the Slovenian lexicographers who were kind enough to participate will gain from the reflection they engaged in during the interviews, as they continue to pursue excellence in their future work.

The extensive interviews of this study yielded copious data, which the present article does not cover in its entirety. Here, in part 1 of our findings, we address drudgery in lexicographic work and the potential of the lexicographer to do harm. Future reports will treat other important topics revealed in the interviews.

Four overarching research questions drove our thinking in the full study and informed the creation of the interview script:

1. What is the philosophical and intellectual framework governing the work of Slovenian lexicographers? What ideas do they all share - across different institutions and projects - as they engage in making dictionaries?

2. What are the main areas of concern and common significant problems that inform the work of Slovenian lexicographers?

3. What do the lexicographers consider both the main strengths and the weaknesses of their current efforts in dictionary creation? What would they most like to change about their practice?

4. What are the differences among our interviewees in their conception of what lexicography is all about?

Approximately sixteen hours of interviews provided us with information related to the above questions. The present article focuses mostly on Research Question 1, with some elements of 4: What do the lexicographers think about before they even sit down to work; what are their reflections on the most important underlying ideas that drive how they perform their duties. A future article will focus more on Research Questions 2 and 3: the specific projects, challenges, and practices of the lexicographers.

\section{The interview script}

Since this project was designed to be replicable in other cultures and countries, the full interview script appears in the Appendix for the use of other researchers. The script consisted of thirteen narrative questions, designed to allow the interviewees to reflect in as much depth as possible on their daily practice as well as their underlying vision of what lexicography or terminography is. (In other words, the script was designed to assist us in answering the overarching questions above.) It took two hours or more to cover all of the questions in the script with each person. The first two interview questions as well as Script 
Questions 7-9 provided us with personal background information as well as information about the lexicographers' daily work, projects, and accomplishments: How did they end up "doing" lexicography and what does a "normal" day look like for them; what project takes up most of their time presently and what product(s) has/have given them the most satisfaction? Script Questions 4-6 treated the philosophical and theoretical underpinnings to their work. We chose to approach this topic with several detailed questions phrased in different ways, in order to appeal to individual styles and thought processes. In addition, because the objective of the grant that funded this work (see Acknowledgements) is to foster collaboration between scientists in the United States and Slovenia and to encourage future cooperative projects, we asked directly in Script Question 6 about any U.S. sources, theories, or practices that may have influenced the Slovenian lexicographers' work. While one interviewee may have said more about (for example) Script Question 5 and another may have elaborated most on Script Question 4, overall we sought and received a comprehensive picture of each person's lexicographic or terminographic world view. Script Questions 10-12 dealt with the problems and constraints the lexicographers face commonly as they strive to deliver high-quality products to dictionary users. Finally, Script Question 13 asked the subjects to recommend different ways in which international cooperation could take place and how it might improve lexicographic practice everywhere.

While all of the interview questions (see Appendix) inform the present article directly or indirectly, two of them, Script Questions 3a and 3b, are our main focus here:

3. The famous English lexicographer, Samuel Johnson, defined the word lexicographer thus, in 1755: "a writer of dictionaries; a harmless drudge, that busies himself in tracing the original, and detailing the signification of words."

a. We would like to know, first: What elements of your own work do you consider "drudgery," hard, menial, or monotonous work?

b. Second, do you think the lexicographer is "harmless?" Does he or she play an invisible, unnoticed social role, or the opposite? How are lexicographers significant to the society of which they are a part?

Interview Question 3a turned out to be less significant than we expected. As will be shown in 9. Lexicography as drudgery? (below), while the lexicographers had opinions on the tedious or monotonous aspects of their work, this is not an issue that preoccupies their thinking, most likely because technology has truly diminished drudgery in modern lexicography. On the other hand, Interview Question 3b (discussed in 10. Harmless or harmful?) gets to the heart of the Slovenian lexicographers' most pressing concerns. They think about the role they play in society and about what they must do to fulfill this role, in 
order to satisfy their users. The analysis presented here is most dependent on the answers our volunteers supplied to Interview Question $3 \mathrm{~b}$.

\section{The selection of interview subjects}

In order to select whom to invite for interviews, we first considered how lexicographic work is organized in Slovenia and what the different contexts are where such work is taking place. First, within the Research Center of the Slovenian Academy of Sciences and Arts there is the Fran Ramovš Institute of the Slovenian Language. The goal of this institute is to compile linguistic materials for the creation of high-quality resources on the Slovenian language. This institute specializes in the following areas: lexicology, etymology, onomastics, dialectology, terminology, and historical dictionaries. In addition to work within the Academy of Sciences, there are ongoing lexicographic projects in a variety of units at the University of Ljubljana (for example, in the Faculty of Arts, the Faculty of Social Sciences, and the Faculty of Computer and Information Science). There is also, for example, an ongoing collaborative project within the Faculties of Arts at the University of Ljubljana and the University of Maribor, in cooperation with the independent Institute of Ethnic Studies in Ljubljana. There are projects led by Trojina, Institute for Applied Slovenian Studies, usually in cooperation with other units.

The focus of this research was on those aspects of lexicographic work that have the greatest significance for the general public rather than areas that might attract primarily language specialists. As a result, there are etymologists, dialectologists, and other lexicographic specialists in Slovenia who were not interviewed because their work is beyond the purview of this study. We wished to discern how the lexicographers interviewed envisage and relate to the users of the contemporary Slovenian language who are the consumers of their products. We sought specialists who work on synchronic topics, and who concentrate on the standard language and terminology rather than on dialectal variation and other topics that are of more interest to scholars than to educated lay persons. We were interested in finding out how "traditional" or not the views of the Slovenian lexicographers are toward their language; to what extent are they accepting of language change and documenting that change in their dictionaries? How do they relate to borrowings into Slovenian from a variety of languages? We also wanted to know what the lexicographers thought about their dictionary users: What is the vision of "the user" that they have in mind when seated at their computers engaging in lexicographic work?

Our request for assistance was well received and we had an adequate number of volunteers; all are prominent lexicographers representing a broad spectrum of work. Only seven persons were interviewed; therefore, this should not be considered a representative sample of the views and thoughts of all of Slovenian lexicography. Due to time constraints and availability of lexicographers, not all specialists could be asked and not all were able to volunteer. This 
study should be considered a sampling of thought-provoking views prevailing within the evolving and viable modern Slovenian lexicographic tradition.

\section{Our interview subjects}

Operating from our script of questions, we interviewed seven Slovenian lexicographers who, collectively, address through their work most of the significant issues facing synchronic theoretical lexicography today. Our interviewees were not anonymous participants. Due to their positions and influence in the field, their reflections are quoted and cited here so that these ideas might advance lexicography worldwide. The interviewees had the option at all times to provide information "off the record," information that is not directly associated with them in what follows. Over the course of an interview lasting two hours or more, the lexicographers were free to make specific comments that would not be directly attributed to them in any subsequent oral or written discussion. In reality, we received very few "off the record" comments; the seven interviewees were candid and forthcoming with their views. What follows is an introduction to the interviewees and their areas of expertise.

Apolonija Gantar is a researcher in the Department of Translation of the Faculty of Arts, University of Ljubljana. She currently collaborates with several different academic and research institutions on projects dealing with: collocations, a new grammar of Slovenian, and non-standard Internet Slovenian.

Nataša Jakop works in the Lexicological Section of the Fran Ramovš Institute within the Academy of Sciences. She is in charge of phraseology for the third edition of The Dictionary of Standard Slovenian [Slovar slovenskega knjižnega jezika], a project begun in 2016.

Iztok Kosem is affiliated with Trojina, the Institute for Applied Slovenian Studies; he also is a researcher in the Faculty of Arts at the University of Ljubljana. He works with several institutions on projects concerning: a Hungarian-Slovenian dictionary, collocations, and a new grammar of Slovenian.

Nina Ledinek is the Head of the Lexicological Section of the Fran Ramovs Institute; she coordinates the work on The Dictionary of Standard Slovenian and also worked on the improvement of the FRAN online dictionary portal.

Jerica Snoj began her lexicographic career during the final stages of preparation of the first edition of The Dictionary of Standard Slovenian (1970-1991). Today she works on the new (third) edition. From 1991, she participated in the planning and production of Slovenian Orthography (Toporišič et al. 2001), which established the norms for the written Slovenian language. After fifteen years, her Dictionary of Slovenian Synonyms came to fruition (Snoj et al. 2016). Among our interviewees, Dr. Snoj is the lexicographer with the longest experience in the field of general as well as special-purpose lexicography.

Anita Srebnik is an instructor of Dutch in the Department of German, Dutch and Swedish in the Faculty of Arts at the University of Ljubljana. She is an independent lexicographer who authored the Slovenian-Dutch European Dic- 
tionary (2006) and the Dutch-Slovenian Dictionary (2007), intended for Slovenian learners of Dutch.

Mojca Žagar Karer is the Head of the Terminological Section of the Fran Ramovš Institute. She has worked on numerous terminological dictionaries, including the Dictionary of Theatre Terms (Sušec Michieli et al. 2007), the Dictionary of Automated Control Systems and Robotics (Karba et al. 2014), and an ongoing dictionary of legal terminology.

\section{Lexicography as drudgery?}

Our interview question (3a) on drudgery was intended to encourage interviewees to speak about what people sometimes would rather not talk about with a stranger: the more unpleasant or undesirable aspects of their work. We guessed that the interviewees would prefer not to complain to us. We assumed they would certainly consider some aspects of lexicographic work to be drudgery (even considering modern technology) and through discussion of such a general topic might begin to speak about both the positive and negative aspects of their work.

The description of the dictionary maker as a drudge, thanks to Samuel Johnson, is familiar to almost every lexicographer. The topic of drudgery has been discussed often in the lexicographic literature, whether or not the words drudge or drudgery are actually used. Recently, Kory Stamper discussed the difference between art and craft in lexicography, and argued that "craft" - because it implies repetition - is a more accurate depiction of dictionary making than "art," which often connotes instantaneous inspiration and creation:

... "[C]raft" implies care, repetitive work, apprenticeship, and practice. ... Defining is the mental equivalent of free throws in basketball: anyone can stand at the free-throw line and sink one occasionally; everyone gets lucky. But the pro is the person who stands at the free-throw line for hours, months, years, perfecting that one motion until it is as fail-safe as humanly possible. ... Craft takes time, both internal and external. You need patience to hone your skill; you need a society willing to wait (and pay) for that skill. (2017: 256).

The repetitive and never-ending nature of lexicographic work is also mentioned by Landau (2001: 396): "Making a dictionary is like painting a bridge: by the time one coat of paint has been applied, the bridge is in need of another." Algeo, while acknowledging the inherent drudgery of the work during the print-dictionary era, emphasizes the dictionary maker's social value: "Although they are relatively anonymous, lexicographers as a class enjoy some of the same popular trust and respect as physicians... . Lexicographers do a real good in recording the language" (1985: 357). This is a recognition shared by Roberts, who, in his foreward to Sharp (2012), notes that "... producing dictionaries is no mere harmless drudgery. ... [D]ictionaries have a crucial role in helping to advance a common language, and to bring at least a degree of order to a 
cacophony of voices" (viii). On the other hand, Schäfer (1984: 196) expressed optimism that "A computerized dictionary should take the 'harmless drudgery,' if not the drudge, out of lexicography." Finally, Sokolowski (2014: 287-288) considers whether the real drudgery might be the lack of knowledge about how the user actually benefits from lexicographic endeavor:

But when they look up particular words, which words are they looking up? The privacy of the act has meant that, for nearly all of the history of published dictionaries, only the users have known. Lexicographers and publishers could never have known whether their labors on any given word were read often - or never. This might make for a grim perspective on one's life's work ("harmless drudge," indeed), but it is obviously understood by all dictionary makers that in order for a dictionary to be generally useful, it must contain all the specific information about words that is likely to be needed. This is the true pact between the user and the dictionary: whenever you have questions, here are answers.

The repetitiveness, the anonymity, and the social significance of dictionary work occupy the thoughts of Slovenian lexicographers just as they occupy their colleagues globally. Among our seven interviewees, the interview question on drudgery resulted in one "no" and six "yes" responses. Four of these were a resounding "yes," while two interviewees gave a "yes, but ..." answer that focused less on the drudgery itself and more on suggestions for mitigating the amount of drudgery in lexicographic work.

The sole terminographer among our interviewees was the only person to answer an unequivocal "no" to the drudgery question. This is not so surprising given that the work approach of terminography is radically distinct from that of other realms of lexicography. Monolingual as well as bilingual lexicographers, phraseologists as well as compilers of synonym and other types of dictionaries, compare contexts of word use or study sense discrimination and composing apt dictionary entries. In contradistinction, the terminographer's work, in the words of Mojca Žagar Karer, Head of the Terminological Section of the Fran Ramovš Institute, is much more "dynamic" and is highly interactive. She does not find any of her tasks to be monotonous because she is engaged constantly with experts from different fields. It is the experts who labor over the definitions (because these definitions have to be precise from the perspective of their field) and Dr. Žagar Karer and other terminographers then edit them. Terminographers do not work alone, in "peace and quiet;" they are constantly on the phone or on email coordinating terminological work or checking fine points in the definitions completed by others. If the terminological work at hand is bilingual or multilingual (which is the norm), Dr. Žagar Karer would most likely need to consult with several different experts to hit upon a general consensus about the most felicitous way for the Slovenian language to convey accurately a concept from the terminology of another language. In short, the terminographer is more like an editor than a lexicographer.

Among those four who provided an emphatic "yes" to our drudgery question were Nataša Jakop and Jerica Snoj, both of the Fran Ramovš Institute 
in the Academy of Sciences. They said that all lexicographic work, all phases of dictionary making are drudgery! Nina Ledinek of the Fran Ramovš Institute and Anita Srebnik, a bilingual lexicographer, used the word "monotonous" to describe many aspects of lexicographic work. Dr. Snoj mentioned the repetitive nature of the work; each task must be performed thousands of times, for as many words as are being investigated; Dr. Jakop pointed out that monotony can lead to waning concentration, a single moment of which can lead to an error: For example, a feminine noun can be labeled mistakenly as neuter. Dr. Ledinek emphasized how difficult it is to analyze a word with numerous concordance lines in a corpus and multiple meanings; there is lots to describe! She noted how extremely difficult it is to be consistent, systematic, and coherent when treating grammatical patterns and collocates. It is also challenging to describe what the standard language is and what the norm is, or to try to describe similar things (i.e. taxonomic sets such as mammals, days of the week) in a unified way. Finally, Dr. Srebnik, who, of these four interviewees is the only one who compiled her dictionary independently, contributed one notstrictly-lexicographic aspect of her work as additional drudgery: fundraising. She was forced to raise money on her own in order to convince the publisher to put her Dutch-Slovenian dictionary into print. Dr. Srebnik stressed that Slovenia needs much better support for bilingual lexicographic work.

Our two "yes, but ..." answers came from lexicographers who acknowledge that many aspects of lexicographic work are drudgery, but whose remarks focused more on how to lessen its amount in lexicographic work. Apolonija Gantar, a researcher at the University of Ljubljana, works on semantic description and discrimination of senses; she acknowledges that this is challenging but not menial work - what is monotonous is the transfer of such work into a database. Dr. Gantar quoted the subtitle of Michael Rundell's conference address (2009: 9): "First banish the drudgery ... then the drudges." She noted that the dictionary is no longer a book; users now expect much more than they did from the print dictionaries of the past. Web-based dictionaries can include lengthy semantic descriptions, grammar, examples, exercises, etymology, phraseology, and other types of information. This is logical: the space limitations of print dictionaries did not allow for all of these possibilities. Dr. Gantar is interested in the roles that automatization and crowd-sourcing play now and can play in the future in reducing the amount of drudgery in lexicography.

Iztok Kosem, a researcher at Trojina, the Institute for Applied Slovenian Studies, and at the University of Ljubljana, has had as his focus over the past five years how to get drudgery out of lexicographic work. He works on identifying the menial and routine tasks of lexicography in order to reduce them. He mentioned GDEX, "Good Dictionary Examples" (Sketch Engine | GDEX n.d.), an electronic tool that takes all available corpus examples and ranks their suitability for a specific meaning or sense according to predetermined criteria. ${ }^{1}$ With the assistance of GDEX, for example, 300 concordance lines from a corpus could be reduced to only the twenty best contexts for the lexicographer to peruse, thus significantly reducing drudgery and saving time. Dr. Kosem con- 
siders that the advent of GDEX is a big step forward in lexicographic work; as corpora have grown to a billion or more words, the problem of too many examples has become ever greater. The answers of Drs. Gantar and Kosem appear to contradict the prediction of Ladislav Zgusta: "The lexicographer has been called a harmless drudge by Dr. Johnson, and he will not advance to a harmless electrician" (1971: 357).

While our subjects had diverse views on exactly how much drudgery is involved in lexicographic work, there was consensus that they find their work extremely rewarding. Jerica Snoj commented that, in the course of the work the lexicographer reaches insights into the language that no one else has - because no one, not even well-educated native speakers, can see linguistic phenomena in quite the same way. And, these insights are what help one to endure. Dr. Snoj stated: "It is a gift for all your suffering but you must be serious in your work to get this satisfaction; otherwise, you can't reach this stage of insight and there will be only suffering! You must invest a lot to reach this satisfaction."

\section{Harmless or harmful?}

The Merriam-Webster Unabridged defines harmless as: "free of or lacking capacity or intent to injure : innocuous." Samuel Johnson, in his formulation "a harmless drudge," was making a statement about the lack of capacity of the dictionary writer to do harm. However, our Slovenian interviewees had clearly given extensive thought to whether the lexicographer has the potential to be harmful; or, in the words of the Merriam-Webster Unabridged: "damaging, troublesome, injurious." The interviewees were very concerned with what for them was the essential nature of their role in society - how the dictionary maker can be a force for good and avoid any potential for harm. For the three authors who undertook this interviewing research, this focus by the seven lexicographers on their ethical position was one of the most interesting findings. The sections below explore this topic in detail.

We discovered a variety of opinions among our interviewees concerning objectivity in lexicography and the relationship of objectivity to harm. Should the lexicographer be objective, describe the language and present it to the user as it is (so that users can evaluate the material and draw their own conclusions), or should the dictionary maker prescribe to users and guide them in what the lexicographer considers to be the best forms of expression in the language? While speaking about Malay dictionary work, Jacobson (1991: 214-215) frames the issue thus:

[There is] some doubt as to what actual role a dictionary should play. Should it be an instrument to prescribe a set of forms that is ruled as standard, correct, good or else should it be one that merely describes the forms frequently used and leaves it then up to the dictionary user to determine which choice is the appropriate one in light of the situation at hand? 
On the other hand, Landau (1989: 32) questions whether there is room for doubt:

All dictionaries based on usage - and all competently done dictionaries must be based on usage - are descriptive. Prescription is impossible to distinguish from bias. Any preferred usage or condemnation of existing usage necessarily reflects the educational or cultural background of the editor ... . Such judgments ... have no place in coloring definitions in a general dictionary any more than editorial opinions belong in straight news articles in the morning newspaper.

Jacobson (1991: 214-215) does not see dictionaries as being limited only to descriptivism - but even if they were, they would nevertheless exercise influence on the norms:

The words that appear in a dictionary represent the correct notations according to the standard norm at a given time and a given place. Therefore, the dictionary in question ... [becomes] the guide for the use of the language that is 'good' or correct. ... Usually, this norm will be accepted for its use if the dictionary is accepted as an authority. ... [Or] the dictionary is considered a recorder of the use of the language without making any judgment according to good or bad .... . So, words, good or bad, need to be recorded. However, the dictionary will (still) become the standardizer of language.

Landau agrees that dictionaries have a standardizing role, whether their editors want them to or not. Despite the goal of objective description, dictionaries reflect "the views and prejudices of the established, well-educated, upper classes" (1989: 303). "One can no more pretend that dictionaries are culturally neutral than one can pretend that any other utilitarian object such as a doorknob or clothes hanger is culturally neutral and without any particular design" (1994: 39). In fact, dictionaries are "powerful forces for the preservation and dissemination of a distinctly cultivated form of expression" (1989: 303).

When our interviewee Apolonija Gantar was previously employed at the Fran Ramovš Institute, she was confronted regularly with the issue of objectivity, because one of her duties was working in the consulting service for the public. Dr. Gantar remembers that, even in those instances where she was not fully satisfied with an answer she provided, the users believed her due to their perception of her status. While Dr. Gantar considers that "people have to take responsibility for their own language and take part in the [lexicographic] decisions," she is aware that most "people don't want gray areas - they want a straightforward answer" as to whether something is "correct" or "incorrect."

Interviewee Nina Ledinek considers that people often consult the dictionary to see what is "right" (even though linguists do not want to encourage this attitude). Another interviewee sees users as going to the lexicographer for a "definite," "black and white" answer. This is the tension inherent in lexicographic work, a tension apparent both to the interviewees and to their colleagues outside of Slovenia. While the users want a dictionary that guides them, lexicographers cannot move away from objective description. Moving 
toward prescription risks failing to depict how most people actually talk and write, which would result in dictionaries of no use and with no credibility or authority.

Iztok Kosem advocates for an objective approach to lexicographic work. He does not see lexicographers as harmless but as individuals with power whose responsibility to the user can be abused. Dr. Kosem views the lexicographer as a mediator between all the complexity of language and the final explanation that appears in the dictionary. This mediating role can be quite influential: If a word does not appear in the dictionary, users might believe that it does not exist at all, or they might be suspicious of it. They might also be suspicious of the dictionary because it omits a word they like - and then they would just go to Google. From Dr. Kosem's perspective, lexicographers have a duty not to be prescriptive. It is the description that really matters, finding the relevant information (evidence) for the users and delivering it quickly to them.

Nataša Jakop is also an advocate for a more descriptive approach. She considers that, as a single individual, the lexicographer is invisible and harmless, but in order to avoid becoming harmful, lexicographers must be objective; they must forget about beliefs and feelings and consider the linguistic material as objectively as the biologist looks at insects. If lexicographers cannot do this and insert their own [prescriptive] views, especially without looking at the linguistic material, then they would become harmful.

Apolonija Gantar noted that while there is no single objective interpretation of what a language is, nevertheless the lexicographer must still strive toward objectivity. A well-developed initial plan and conceptualization of the dictionary to be compiled can contribute to the overall objectivity of the final work. On the other hand, a too-rigid adherence to an initial plan could be harmful, if some specific set of objective data indicates that you need to do things differently. An example of this, according to Dr. Gantar, is the treatment of gerundial forms in the first edition of the Dictionary of Standard Slovenian. There, gerunds were only described syntactically, with no accompanying lexical explanation. The editors at the Academy of Sciences realized it was a mistake but did not change it, despite the fact that some gerunds in Slovenian are not semantically linked to the verb of origin in a transparent manner, so that a strictly syntactic definition will be obscure. [For example: skakanje: glagolnik od skakati 'a gerund from [the verb] to jump' instead of: 'the process of jumping; a gerund from [the verb] to jump']. Dr. Gantar's comment shows that the goals of objectivity and descriptive accuracy, despite the lexicographers' best intentions, can be quite elusive.

While Nina Ledinek, like Nataša Jakop, considers that lexicographers are not visible, she emphasizes that they must be socially responsible and sensitive to the different groups in society: Just this, the fact that they must demonstrate sensitivity, shows that lexicographers do play a significant role. Dr. Ledinek maintains that the Dictionary of Standard Slovenian does and should have a normative value; their language has connected Slovenians throughout their history - a 
history which until recently has always been that of a minority people surviving in larger regimes. Dr. Ledinek's comments bring home the descriptive challenge posed by a language like Slovenian with only two million speakers; while objectivity is still very much in the focus of Slovenian lexicographers, they also must consider the role of their language very differently than would any lexicographer of English. Anita Srebnik notes that other languages bring the outside world to Slovenia and allow Slovenians to communicate when they cross any border. Slovenia might be small but it cannot live without exchange, and an asset of its people is the ability to learn other languages well. Her comments bring to light the important relationship of Slovenian to other languages, as depicted in its bilingual dictionaries. Bilingual lexicography takes on a special significance in the case of such a (relatively) small language.

Dr. Srebnik finds it deplorable that the public regards only some dictionaries as conveyers of the norm, as authorities on the language. For the Slovenian media, she maintains, this authority only accrues to the work of the Academy of Sciences, when in reality there are many other worthy and authoritative projects. In her eyes, it is the media (rather than the lexicographer) that causes harm because it limits the focus - and attributes the power and authority - to a small number of lexicographers and projects. In particular, Dr. Srebnik faults the lack of status and authority for bilingual lexicography; in reality, bilingual lexicographers treat not just equivalence in two languages but also connotation and cultural differences. Dr. Srebnik's point about the societal status of bilingual dictionaries highlights something that is often overlooked: It is not only monolingual, but also bilingual dictionaries that have a role in the maintenance of the norm, and the power to do (or not do) harm.

Mojca Žagar Karer, the sole terminographer of our study, sharply distinguishes her practice from that of lexicographers and has a very different take on the whole notion of objectivity. For Dr. Žagar Karer, it is clear: Lexicography is more subjective and therefore might not be harmless. Because lexicographers write definitions and analyze meaning themselves, they are subjective; in other words, definition writing and meaning analysis, as non-descriptive activities, have a potential for harm. Terminographers, in her perspective, must be objective because they must be credible for the subject field and for the society. They are trying to create quality language resources which are useful for translators, language editors, and others. As was mentioned, Dr. Žagar Karer's work role is closer to that of an editor than a lexicographer, in that she gathers the terminological definitions written by specialists in a given field and edits toward reaching consensus among those she consults. While Dr. Žagar Karer's perception of objectivity is reasonable, in the case of terminography, the "burden" of objectivity does not disappear but is simply transferred from the terminographer/editor to those field specialists who actually write the definitions. It is reasonable to suppose that, given their lack of lexicographic experience, some field specialists do inadvertently bring their personal beliefs, perceptions, and prescriptive ideas to definition writing, what for them is a relatively new 
endeavor. If two field specialists were to disagree about which of two terms is the best to designate a given concept, then certainly we would have two persons striving toward objectivity of description who come up with different results.

Jerica Snoj stressed that, regardless of how they are regarded (or ignored), lexicographers are very important for the society; their dictionaries bring the description of language to users, thereby helping users to express their thoughts in an appropriate way. When a new dictionary appears, a new insight into the language is opened up. Dr. Snoj considers that the dictionary has a very important role in exploring the possibilities of a language; Nataša Jakop cites the significant role it plays in the preservation of cultural heritage. Dr. Jakop's point is of special significance for the lexicography of any language with a relatively small number of speakers: Preservation for such languages is crucial.

Whether visible or invisible, whether harmless, whether a drudge, the lexicographer is the source of insight into a given language. The responsibility to provide these insights to users in the most ethical way possible is something that all of our interviewees agree on.

\section{Conclusions}

It has been more than 260 years since Samuel Johnson defined lexicographer as a "harmless drudge." Our interviews with seven working Slovenian lexicographers reveal many opinions on the viability of his definition today, and the insights of these interviewees are significant for the development of lexicographic theory broadly construed. The Slovenian lexicographers, all distinguished and experienced modern practitioners, accept some implications of Johnson's metaphor while they categorically reject others. First, they certainly acknowledge that some aspects of their work can be tedious, despite the more pervasive use of technology today. While their strong commitment and their focus on the end result of lexicographic endeavor allow them to accept drudgery as part of the picture, the interviewees are acutely aware that repetitive work has pitfalls, such as the possibility for attention to wane and mistakes to be introduced. Because of the potential deleterious effects of monotony on the quality of final lexicographic products, some of the interviewees actively work toward the development of new technologies to replace the hard, repetitive and routine lexicographic work that is still done by people.

The Johnsonian notion of "harmless drudge" contains not just tedium but also anonymity. Slovenian lexicographers know that the dictionary maker usually labors in isolation, unknown to the public. What is of more concern to our interviewees than anonymity is the lack of understanding in the public of what the lexicographer actually does. The lack of public awareness can contribute to an overestimation of the lexicographer's authority, which in turn may lead to the disengagement of the public from interest in the Slovenian language. After all, if it is only the lexicographers who know the language, then there is noth- 
ing for the educated language user to think about or do except follow the "advice" that (they think) the dictionary is trying to give. Conversely, as the bilingual lexicographer in the group of interviewees pointed out, a lack of public awareness can undermine the valuing of dictionary work by the media or by society at large - to the detriment of production of sorely needed bilingual and monolingual dictionaries.

While they concede the reality of problems engendered by drudgery and anonymity, the Slovenian lexicographers interviewed would reject outright the idea that the dictionary writer is a priori "harmless." Because the interviewees have reflected extensively on the social implications of their profession, they perceive many possibilities for harm and are motivated to avoid it. It is the ethical responsibility of the lexicographer to the dictionary user that is the most important preventative of harm. If a lexicographer were to ignore or misrepresent language facts as represented in a corpus or other lexicographic source and veer away from linguistic description, this imposition of personal bias would most certainly be socially harmful.

The serious discussion engaged in during this study by the seven Slovenian specialists should not leave the reader with the impression that for them, lexicography is a grim and onerous business; quite the contrary. Certainly, as one interviewee put it, lexicography requires a tremendous persistence because, despite constantly improving facilities and research tools, there is still a lot of menial work. Surely, media portrayals and the society's general misapprehensions about what lexicography is complicate the already-challenging work of linguistic description. Nevertheless, the six Slovenian lexicographers and one terminographer spoke frequently about "satisfaction": the satisfaction of gaining real insight into the language, the satisfaction of meeting the language needs of the users, and the satisfaction of helping users to engage more fully with a language that is such an important part of Slovenian identity.

\section{Endnote}

1. For more on how Sketch Engine | GDEX works and what makes for a good corpus example for lexicography, see Kilgarriff et al. (2008: 426): Examples of criteria mentioned are typicality — an example should exhibit "frequent and well dispersed patterns of usage;" informativeness - the example should "elucidate the definition;" intelligibility — the example should avoid "difficult lexis and structures, puzzling or distracting names, anaphoric references or other deictics which cannot be understood without access to the wider context." See also Atkins and Rundell (2008: 458-461).

\section{Acknowledgements}

This study could not have taken place without the full cooperation and consummate generosity of our seven Slovenian lexicographer-interviewees. The 
participants were candid, forthcoming, reflective, insightful. Interviewing them was not like work but was a pleasure. Some of the busiest people in Slovenia its lexicographers - took the time to move our research forward. As this study reveals, they bring to their practical lexicographic tasks a highly developed sense of ethics and responsibility. Now, by participating in this study, they bring the same sense of duty to furthering the theoretical development of lexicography internationally. Many thanks to: Apolonija Gantar, Nataša Jakop, Iztok Kosem, Nina Ledinek, Jerica Snoj, Anita Srebnik, and Mojca Žagar Karer! We would also like to thank Marko Snoj, the director of the Fran Ramovš Institute of the Slovenian Academy of Sciences, for welcoming us there. We hope to see you again in the future.

The authors acknowledge the project, Lexicographic exchange as a way of building bridges between Slovenian and American lexicographic philosophy, governing principles, goals, and work tools, No. BI-US/16-17-053, which was financially supported by the Slovenian Research Agency. They also acknowledge the approval (20 February 2017) of the New Jersey City University (NJCU) Institutional Review Board for the Protection of Human Participants in Research. Donna Farina thanks NJCU for travel support to Ljubljana, Slovenia, as well as released time support from its Separately Budgeted Research program. The authors thank NJCU, in particular Tamara Cunningham, Assistant Vice President for Global Initiatives, for providing housing and hospitality to Alenka Vrbinc and Marjeta Vrbinc during their research visit to the United States.

\section{References}

Algeo, John. 1985. Harmless Drudgery. American Speech 60(4): 357-361.

Ammon, Ulrich and Marlis Hellinger (Eds.). 1991. Status Change of Languages. Berlin/New York: Walter de Gruyter.

Atkins, Beryl T. Sue and Michael Rundell. 2008. The Oxford Guide to Practical Lexicography. Oxford/ New York: Oxford University Press.

Bajec, Anton et al. 1970. Slovar slovenskega knjižnega jezika [Dictionary of Standard Slovenian]. Vol. 1, A-H. Ljubljana: Državna založba Slovenije.

Béjoint, Henri. 2010. The Lexicography of English. Oxford: Oxford University Press.

Béjoint, Henri. 2016. Dictionaries for General Users: History and Development; Current Issues. Durkin, Philip (Ed.). 2016: 7-24.

Bernal, Elisenda and Janet DeCesaris (Eds.). 2008. Proceedings of the XIII EURALEX International Congress, Barcelona, 15-19 July 2008. Barcelona: Universitat Pompeu Fabra, Institut Universitari de Lingüística Aplicada.

Cowie, Anthony P. (Ed.). 2009. The Oxford History of English Lexicography. Volume I: General-purpose Dictionaries. Oxford: Oxford University Press.

Durkin, Philip (Ed.). 2016. The Oxford Handbook of Lexicography. Oxford: Oxford University Press. [Online version.] 
Farina, Donna M.T.Cr. and George Durman. 2009. Bilingual Dictionaries of English and Russian in the Eighteenth to the Twentieth Centuries. Cowie, Anthony P. (Ed.). 2009: 105-126.

Farina, Donna M.T.Cr. and George Durman. 2012. "Academic Hooliganism" or "False Gold"? The Reception of Baudouin de Courtenay's Russian Dictionary. Dictionaries: Journal of the Dictionary Society of North America 33: 1-41.

Fontenelle, Thierry. 2016. Bilingual Dictionaries: History and Development; Current Issues. Durkin, Philip (Ed.). 2016: 44-61.

Gantar, Polona. 2015. Leksikografski opis slovenščine v digitalnem okolju [Lexicographic Description of Slovenian in a Digital Environment]. (Zbirka Sporazumevanje). First edition, e-publication. Ljubljana: Znanstvena založba Filozofske fakultete.

Gliha Komac, Nataša, Nataša Jakop, Janoš Ježovnik, Simona Klemenčič, Domen Krvina, Nina Ledinek, Tanja Mirtič, Andrej Perdih, Špela Petric, Marko Snoj and Andreja Žele (Eds.). 2015. Osnutek koncepta novega razlagalnega slovarja slovenskega knjižnega jezika [Preliminary Conceptualization of a New Explanatory Dictionary of Standard Slovenian]. Različica 1.1. Ljubljana: Inštitut za slovenski jezik Frana Ramovša; Znanstvenoraziskovalni center Slovenske akademije znanosti in umetnosti.

Gorjanc, Vojko, Polona Gantar, Iztok Kosem and Simon Krek (Eds.). 2015. Slovar sodobne slovenščine: problemi in rešitve [Dictionary of Modern Slovene: Problems and Solutions]. (Zbirka Prevodoslovje in uporabno jezikoslovje). First edition. Ljubljana: Znanstvena založba Filozofske fakultete.

Gorjanc, Vojko, Polona Gantar, Iztok Kosem and Simon Krek (Eds.). 2017. Dictionary of Modern Slovene: Problems and solutions. (Book series Prevodoslovje in uporabno jezikoslovje). First edition, e-edition. Ljubljana: Ljubljana University Press, Faculty of Arts. [This is the translation of Gorjanc et al. 2015.]

Granger, Sylviane and Magali Paquot (Eds.). 2009. eLex2009: eLexicography in the 21st Century: New Challenges, New Applications. Conference abstracts of eLex2009, 22-24 October 2009. Louvainla-Neuve: Centre for English Corpus Linguistics, Université de catholique de Louvain.

Harmful. n.d. Merriam-Webster Unabridged [online]. Retrieved from http://unabridged.merriamwebster.com/unabridged/harmful.

Harmless. n.d. Merriam-Webster Unabridged [online]. Retrieved from http://unabridged.merriamwebster.com/unabridged/harmless.

Jackson, Howard. 2002. Lexicography: An Introduction. London/New York: Routledge.

Jacobson, Rodolfo. 1991. In Search of Status: Bahasa Malaysia for National Unification. Ammon, Ulrich and Marlis Hellinger (Eds.). 1991: 200-226.

Karba, Rihard, Gorazd Karer, Juš Kocijan, Tadej Bajd, Mojca Žagar Karer and Tanja Fajfar (Eds.). 2014. Terminološki slovar avtomatike [Dictionary of Automated Control Systems and Robotics]. Zbirka Slovarji. Ljubljana: Založba ZRC.

Kilgarriff, Adam, Miloš Husák, Katy McAdam, Michael Rundell and Pavel Rychlý. 2008. GDEX: Automatically Finding Good Dictionary Examples in a Corpus. Bernal, Elisenda and Janet DeCesaris (Eds.). 2008: 425-432.

Landau, Sidney I. 1989. Dictionaries: The Art and Craft of Lexicography. Cambridge: Cambridge University Press.

Landau, Sidney I. 1994. The Expression of Changing Social Values in Dictionaries: Focus on Family Relationships. Little, Greta D. and Michael Montgomery (Eds.). 1994: 32-39. 
Landau, Sidney I. 2001. Dictionaries: The Art and Craft of Lexicography. Second Edition. New York/ Cambridge: Cambridge University Press.

Ledinek, Nina, Kozma Ahačič and Andrej Perdih. 2015. Fran: slovarji Inštituta za slovenski jezik Frana Ramovša ZRC SAZU, Vodnik [A Guide to Fran: The Dictionaries from the Fran Ramovš Institute of the Slovenian Language in the Research Center of the Slovenian Academy of Sciences and Arts]. (Zbirka Fran). Različica 1.0. Ljubljana: Založba ZRC.

Little, Greta D. and Michael Montgomery (Eds.). 1994. Centennial Usage Studies. (Publication of the American Dialect Society 78.) Tuscaloosa: University of Alabama Press.

Rundell, Michael. 2009. The Road to Automated Lexicography: First Banish the Drudgery ... Then the Drudges? Granger, Sylviane and Magali Paquot (Eds.). 2009: 9-10.

Schäfer, Jürgen. 1984. The History of Ideas and Cross-Referencing in the Future EMED. Dictionaries: Journal of the Dictionary Society of North America 6: 182-198.

Shapiro, Rebecca (Ed.). 2017. Fixing Babel: An Historical Anthology of Applied Lexicography. Lewisburg: Bucknell University Press.

Sharp, Gene. 2012. Sharp's Dictionary of Power and Struggle: Language of Civil Resistance in Conflicts. Oxford: Oxford University Press.

Sketch Engine | GDEX.n.d. https://www.sketchengine.co.uk/user-guide/user-manual/concordanceintroduction/gdex.

Snoj, Jerica. 2004. Tipologija slovarske večpomenskosti slovenskih samostalnikov [The Lexicographic Treatment of Polysemous Nouns in Slovenian]. (Zbirka Linguistica et philologica). Ljubljana: Založba ZRC, ZRC SAZU.

Snoj, Jerica, Martin Ahlin, Branka Lazar and Zvonka Praznik. 2016. Sinonimni slovar slovenskega jezika [Dictionary of Slovenian Synonyms]. First edition. Ljubljana: Založba ZRC.

Sokolowski, Peter. 2014. The Dictionary as Data. Dictionaries: Journal of the Dictionary Society of North America 35: 287-298.

Srebnik, Anita. 2006. Slovensko-nizozemski evropski slovar [Slovenian-Dutch European Dictionary]. (Zbirka Evropski slovarji). Ljubljana: Cankarjeva založba.

Srebnik, Anita. 2007. Nizozemsko slovenski slovar = Nederlands Sloveens woordenboek [Dutch-Slovenian Dictionary]. (Slovarji DZS). First edition. Ljubljana: DZS.

Srebnik, Anita. 2015. Jezikovnotehnološki postopek obračanja dvojezičnih slovarjev [The Technology and Linguistics behind the Process of Reversing Bilingual Dictionaries]. Praha: Verbum.

Stamper, Kory. 2017. Word by Word: The Secret Life of Dictionaries. New York: Pantheon Books.

Sušec Michieli, Barbara, Marjeta Humar, Katarina Podbevšek, Slavka Lokar, Edi Majaron, Viktor Molka, Janko Moder, Miran Herzog, Ana Kocjančič and Mojca Žagar Karer (Eds.). 2007. Gledališki terminološki slovar [Dictionary of Theatre Terms]. Zbirka Slovarji. Ljubljana: Založba ZRC.

Toporišič, Jože, Franc Jakopin, Janko Moder, Janez Dular, Stane Suhadolnik, Janez Menart, Breda Pogorelec, Kajetan Gantar, Martin Ahlin and Milena Hajnšek-Holz (Eds.). 2001. Slovenski pravopis [Slovenian Orthography]. Ljubljana: Založba ZRC.

Žagar Karer, Mojca. 2011. Terminologija med slovarjem in besedilom: analiza elektrotehniške terminologije [Terminology from the Text to the Dictionary: Analysis of Electro-technical Terminology]. (Zbirka Linguistica et philologica 26). Ljubljana: Založba ZRC, ZRC SAZU.

Zgusta, Ladislav. 1971. Manual of Lexicography. Prague: Academia / The Hague/Paris: Mouton. 


\section{Appendix}

\section{Interview script}

\section{Beginning of interview}

We want to thank you very kindly for agreeing to work with us on this project. Our working title is: "Slovenian Lexicographers at Work." Our goal is to add to the worldwide understanding of what lexicographic work is by focusing on work in this country. We consider that the practices in Slovenia should be known and will prove relevant to lexicographers everywhere.

As indicated by the statement you signed, your remarks are not anonymous; we would like to mention you by name and highlight your ideas in any resulting publications. But, on the other hand, if any specific remark you make is not one that you want attributed to you by name, just tell us that it is "off the record." In that case, we would quote you or cite you generally, using language such as: "Some of our interviewees considered that ...."

\section{Questions}

1. First of all, can you tell us a little bit about yourself? Why were you attracted to the field of lexicography? How did you end up doing what you do today?

2. Can you describe your daily work as a lexicographer? What are the main activities that you do on a daily, weekly, or monthly basis? What aspects of your work do you like best?

3. The famous English lexicographer, Samuel Johnson, defined the word lexicographer thus, in 1755: "a writer of dictionaries; a harmless drudge, that busies himself in tracing the original, and detailing the signification of words."

a. We would like to know, first: What elements of your own work do you consider "drudgery:" hard, menial, or monotonous work?

b. Second, do you think the lexicographer is "harmless?" Does he or she play an invisible, unnoticed social role, or the opposite? How are lexicographers significant to the society of which they are a part?

4. What is the philosophical and theoretical framework that governs your work? In other words, what is the "umbrella" of ideas under which you do everything that you do?

(Follow-up to Question 4, if needed: What are the "big" ideas that influence how you go about your habitual work as a lexicographer?) 
5. Can you explain what are the two or three driving principles that govern your work as a lexicographer? How do you think about these principles as you engage in the minute tasks which lexicographers of necessity must perform?

6. The two previous questions tried to understand more the theoretical and philosophical basis for your lexicographic work. Now we wish to ask: Can you name any theories or practices used in other countries, including the U.S., that inform your own lexicographic work? Or, perhaps when you formulated the principles of your work you incorporated some ideas from abroad?

7. Related to the previous question, have you joined any lexicographic organizations such as the Dictionary Society of North America or EURALEX? Do your memberships of this type affect your work? How?

8. Can you describe two or three of the current projects that you are involved with? We are looking to describe, as completely as possible, what is going on today in Slovenian lexicography. We are also very interested in any future projects that are in the planning stages.

9. In recent years, what are the most noteworthy accomplishments in the work of you and your immediate colleagues?

10. It goes without saying that lexicographic work takes place in the real world and is subject to the usual constraints and challenges of any practical work. In particular, there are always budgetary constraints, but not only budgetary. We would like to know: How is your work challenged by a variety of circumstances; what are the challenges and constraints?

11. Can you name the major strengths of your work situation? What is a best practice for you and your colleagues (e.g., access to different information/ sources, user-friendly dictionary-making software, cooperation with IT specialists and/or corpus linguists and/or experts from other fields, etc.)? What affects most positively the compilation of your dictionaries?

12. If you could change one thing about the circumstances of your lexicographic work, what would it be? If you could change one feature of the lexicographic philosophy/theory that underpins your work, what would it be?

13. Could you offer us some suggestions? How do you think the cooperation and exchange of ideas between Slovenian and American lexicographers can be encouraged? Do you consider that more cooperation would improve lexicographic work in Slovenia, the U.S., and beyond? 